\title{
Profile of Feeding and Nutrient Fulfillment Bali Cows On Farm Management in Bali at Dry Season
}

\author{
Sudita I.D.N ${ }^{1}$, I.G.A.M. Putra Sanjaya ${ }^{2}$, N.K. Mardewi ${ }^{3}$ \\ \{idnsudita@gmail.com ${ }^{1}$ \} \\ Farmed Animal Science, Faculty of Agriculture Warmadewa University ${ }^{123}$
}

\begin{abstract}
In cattle breeding which is still tradisional in Bali, nutrition and nutritional fulfillment are varied. This study aims to determine the profile and fulfillment of nutrition in the maintenance management of Bali cows in Bali during the dry season. The study used survey and observation methods on 27 livestock groups "Simantri" with topography of different places (lowland, plains, and plateau) in 3 regencies each of 3 farmers as samples. The known variables are feed, amount of feed given, diversity and proportion, and amount of nutrients in feed. The results showed that only $36,36 \%$ farmers had land for forage crops with an area between 1-5 acres, most of the land planted with shrubs and tree legumes did not meet the needs of their livestock. The average amount of feed given to livestock as much as $33.15 \mathrm{~kg}$ is not sufficient for livestock needs based on $10 \%$ of body weight in fresh weight. Most ( $81.8 \%$ ) farmers provide field grass in rations, and $27.3 \%$ are available to provide untreated rice straw. The average proportion of grass in the ration was $58.46 \%$, elephant grass $6.69 \%$, rice straw $5.67 \%$, broadleaf $1.06 \%$, and gamal $3.17 \%$. Based on the composition of the ration, the protein fulfillment is $648.71 \mathrm{~g}$ and energy is $13.820 .18 \mathrm{kcal}$ ME, still above the basic necessities of life. From this study it can be concluded that the dry season, pregnancy food diversity in many problems, while the fulfillment of nutrients there is still a basic need for Bali cows in Bali.
\end{abstract}

Keywords: Dry Season, Diversity and Excess Feed Ingredients, Nutritional Fulfillment, Bali Cows.

\section{Introduction}

Bali cattle are national assets that must be preserved with various advantages they have as beef cattle to meet the increasing meat consumption needs. On the one hand it is feared that genetic degradation is caused by various factors in maintenance management by farmers. Efforts have been made by the government such as the selection of superior males to produce frozen semen in the implementation of the Artificial Insemination Program (AI) has not run optimally. In addition, the provincial government of Bali since 2009/2010 has formed livestock groups throughout the districts / cities through the "Simantri" (Integrated Agriculture Management System) program, until 2017 have been formed 750 groups. Conceptually the Simantri program is very good, in addition to spurring the development of livestock groups in an effort to increase livestock populations, the utilization of sewage into organic fertilizer to increase food crop productivity, and increase farmers' income.

In the implementation of the Simantri program, the government has provided assistance packages to groups in the form of: livestock seedlings, colony cages, fertilizer processing facilities and biogas manufacturing plants. As for the management of livestock maintenance, it 
depends on the ability of each individual member of the group, especially in the provision and feeding. Provision and feeding is strongly influenced by environmental conditions, namely: land use in agricultural systems, environmental temperature / temperature, and season.

There are differences in feed availability in systems and cropping patterns of rice fields and moorings / plantations [1], which affect feed diversity and nutrient fulfillment. Whereas for the environment and season temperature, especially during the dry season, the source and availability of food tends to decrease. The result is very influential on the diversity of feed and nutrient fulfillment for livestock. Provision of feed for cows in Bali is still carried out in the pattern of smallholder farming in traditional farming systems. Cattle breeding in general is always integrated with traditional agriculture (agroforestry systems), there is no special land provided for planting forage [2], low value of effectiveness and efficiency and slow absorption of innovation and technology [3].

Therefore the amount of feed given, the diversity of feed and nutrient fulfillment for the main Balinese cattle in Bali will vary depending on the season. The results of the study [4] in the rainy season (February-April) get no difference in the diversity of feed at different altitudes, energy and protein obtained by the Bali cows have been fulfilled above the basic life needs. To complete the data during the dry season and the peak of the dry season, further research is needed, so that a profile of feed and nutrient fulfillment can be made for the Bali cattle cows in Bali.

\section{Methodology}

\subsection{Determination of Location and Research Samples}

The Simantri Program spread throughout the Province of Bali in 9 Regencies / Cities, then stratification sampling was chosen in 3 Regencies namely: Tabanan (wet / dominant area of rice fields), Buleleng (dominant plantation area), and Karangasem (dry area / dominant dry land).

In each district are grouped into 3 altitude places, namely: lowlands, plains, and plateu. Each place height was chosen by purposive sampling 1 Simantri group, and in groups selected by random sampling 3 farmers as samples.

\subsection{Research methods}

Retrieval of research data using the survey method by interview and observation. Interviews were conducted using a questionnaire (questionnaire) to the farmers, while observing by making direct observations of feeding.

\subsection{Measured Variables}

Taking field data through interviews and observations includes: availability of feed ingredients, amount of feed given, diversity of feed ingredients in rations, proportion of each feed ingredient, sampling of feed ingredients then analyzed by the laboratory to determine the consumption of dry matter (DM), crude fiber (CF), protein (CP) and energy (ME).

\subsection{Data analysis}

Data were analyzed using descriptive analysis by tabulating data to get an average, then interpreted to draw a conclusion. 


\section{Results and Discussion}

\subsection{Forage Availability}

Maintenance of cows by farmers in the "Simantri" group is not much different from the maintenance of cattle in general by the people in Bali who are still traditional. Therefore, the availability of feed is still following the popular pattern, only $36.36 \%$ of farmers have special forage planting. Of the number that has the most land $(50.0 \%)$, the area is between $1-5$ acres (Table 1). Some reasons are not to provide special land for planting forage because besides having no land, you can still get forage in other people's places or on public land. This reinforces the statement [3] and [5] that cattle farming is still carried out with a traditional pattern of populace. In accordance with the results of the study [4] that the ownership of forage land and the availability of forage in the Simantri livestock group in Bali is very limited, so that it is not sufficient for the livestock especially during the dry season. Cattle farming is still carried out with agroforestry systems, there is no special land for forage planting only in shipyards planted with elephant grass for the rainy season [2].

Table 1. Availability of Forage Feed

\begin{tabular}{|c|c|c|c|c|c|}
\hline No & Variable & \multicolumn{4}{|c|}{ Measurement results } \\
\hline 1 & Have land for planting forage & $\begin{array}{c}\text { Yes } \\
(36,36 \%)\end{array}$ & $\begin{array}{c}\text { No } \\
(63,63 \%)\end{array}$ & \multicolumn{2}{|c|}{$\begin{array}{l}\text { Reason not having: } \\
\text { a. No lands } \\
\text { b. Many available around }\end{array}$} \\
\hline 2 & $\begin{array}{l}\text { Average amount of land } \\
\text { owned }\end{array}$ & $\begin{array}{l}1-5 \text { acre } \\
(50,0 \%)\end{array}$ & $\begin{array}{l}6-10 \text { acre } \\
(35,72 \%)\end{array}$ & $\begin{array}{l}11-15 \text { acre } \\
(7,14 \%)\end{array}$ & $\begin{array}{l}>15 \text { acre } \\
(7,14 \%)\end{array}$ \\
\hline 3 & $\begin{array}{l}\text { Forage types planted or } \\
\text { owned on land }\end{array}$ & $\begin{array}{l}\text { Pennisitum } \\
(31,82 \%)\end{array}$ & $\begin{array}{l}\text { Setaria } \\
(-)\end{array}$ & $\begin{array}{c}\text { Legume tree } \\
(40,91 \%)\end{array}$ & $\begin{array}{c}\text { Native grass } \\
(27,27 \%)\end{array}$ \\
\hline 4 & Adequate livestock needs & $\begin{array}{c}\text { Yes } \\
(22,72 \%)\end{array}$ & $\begin{array}{c}\text { No } \\
(77,28 \%)\end{array}$ & \multicolumn{2}{|c|}{$\begin{array}{l}\text { How to overcome } \\
\text { shortcomings: } \\
\text { a. Getting elsewhere } \\
\text { b. Buying }\end{array}$} \\
\hline
\end{tabular}

In general, the type of forage planted is elephant grass, while the legume tree is planted by the community as a guardrail of dry land in the form of Gliricidia ("gamal") plants. With low forage planting by farmers, the majority of farmers $(77.28 \%)$ stated lack of feed. Therefore farmers look for feed to take the needs of livestock looking for other people, some are close and also far from their homes. In some places breeders buy feed to take the needs of their livestock, this also provides an opportunity for some people as a business providing food for sale services, especially Elephant grass (Pennisitum).

\subsection{Feeding}

The results showed that $68.19 \%$ of the breeders gave food not paying attention to their physiological status, even if there were some breeders only increasing the amount (volume) given and providing additional feed in the form of rice bran and salt (Table 2). This shows that the knowledge of farmers in feeding for main cows is still lacking. Cows need different feeds with fattening cows, because they have to be adapted to their physiological status (dry period, pregnant, childbirth and lactation). Entering the pregnancy period, the cows needs more feed, especially for the development of the womb in the womb until near birth. Therefore, livestock 
appearance is an interaction between genetic and environmental (feed) since fertilization [6], because environmental factors cannot be inherited like genetic factors [7], [8].

Research data also shows that farmers' knowledge of the substances needed by livestock is still low, only $22.37 \%$ said they knew, and most $(81.8 \%)$ gave field grass. So this needs attention, moreover there are still many farmers $(40.90 \%)$ who do not know which types of feed ingredients are good for their livestock. They only know that Elephant grass and leaves are good for livestock. There are still many types of feed ingredients that are very good given to parent cattle such as gamal, lamtoro, kaliandra. This type of feed ingredients besides having high protein content, also has special properties that are good for cattle. Leguminous drugs have the advantage of increasing nutrient utilization for production and environmental sustainability, because some legumes containing tannins can reduce methane emissions and increase production of $\mathrm{NH} 3-\mathrm{N}$ from the rumen as a result of direct or indirect inhibition of methanogens [9].

Table 2. Provision of Parent Cow Feed

\begin{tabular}{|c|c|c|c|c|}
\hline No & Variable & \multicolumn{3}{|c|}{ Measurement results } \\
\hline 1 & $\begin{array}{l}\text { Feeding is based on } \\
\text { physiological status of } \\
\text { livestock }\end{array}$ & $\begin{array}{c}\text { Yes } \\
(31,81 \%)\end{array}$ & $\begin{array}{c}\text { No } \\
(68,19 \%)\end{array}$ & $\begin{array}{l}\text { Types of treatment: } \\
\text { a. Amount of volume } \\
\text { b. Amount of feed additive }\end{array}$ \\
\hline 3 & Provide additional feed & $\begin{array}{c}\text { Yes } \\
(59,10 \%)\end{array}$ & \multirow{2}{*}{\multicolumn{2}{|c|}{$\begin{array}{l}\text { Additional fe } \\
\text { a. Rice bra } \\
\text { b. Salt } \\
\quad \text { No } \\
\quad(77,63 \%)\end{array}$}} \\
\hline 3 & $\begin{array}{l}\text { Farmers know the substances } \\
\text { needed by livestock }\end{array}$ & $\begin{array}{c}\text { Yes } \\
(22,37 \%)\end{array}$ & & \\
\hline 4 & $\begin{array}{l}\text { Farmers know good feed } \\
\text { ingredients for their livestock }\end{array}$ & $\begin{array}{c}\text { Yes } \\
(59,10 \%)\end{array}$ & $\begin{array}{c}\text { No } \\
(40,90 \%)\end{array}$ & $\begin{array}{l}\text { Good type of feed } \\
\text { ingredients } \\
\text { a. Elephan grass } \\
\text { b. Leguminoseae }\end{array}$ \\
\hline 7 & $\begin{array}{l}\text { Types of feed ingredients in } \\
\text { rations provided by farmers }\end{array}$ & $\begin{array}{l}\text { Percentage } \\
(36,4 \%) \\
(81,8 \%) \\
(27,3 \%) \\
(9,10 \%) \\
(9,10 \%)\end{array}$ & \multicolumn{2}{|c|}{$\begin{array}{l}\text { Type of feed : } \\
\text { 1. Elephant grass } \\
\text { 2. Native grass } \\
\text { 3. Rice straw } \\
\text { 4. Broadleaf } \\
\text { 5. Gamal (Gliricidia) }\end{array}$} \\
\hline
\end{tabular}

\subsection{Average Giving Amount and Ration Composition}

In Table 3 it can be seen that the use of native grass in rations for bali cattle cows is quite high (average 58.46\%) in the lowlands, even the use of rice straw without processing is high enough to enter the dry season. While the addition of broadleaf (hulls) and legume shrubs / trees is very small. That protein (CP) in legumes is higher than grass (129 compared to $115 \mathrm{~g}$ / $\mathrm{kg} \mathrm{DM}$ ) [10]. Therefore the choice of forage species and harvest time affects $\mathrm{CH} 4$ emissions, while the ability of livestock to reduce $\mathrm{CH} 4$ does not interact with forage characteristics [11]. 
Table 3. Average Feed Amount and Feed Composition

\begin{tabular}{|c|c|c|c|c|c|}
\hline \multirow[t]{2}{*}{ No. } & \multirow[t]{2}{*}{ Feed ingredients } & \multicolumn{4}{|c|}{ Amount in ration (fresh weight) } \\
\hline & & Law land & Plains & Plateu & Everage \\
\hline 1 & Native grass $(\mathrm{kg}, \%)$ & $\begin{array}{c}24,78 \\
(69,37 \%)\end{array}$ & $\begin{array}{c}21,90 \\
(67,32 \%)\end{array}$ & $\begin{array}{c}11,47 \\
(36,76 \%)\end{array}$ & $\begin{array}{l}19,38 \\
(58,46 \%)\end{array}$ \\
\hline 2 & Elephant grass (kg, \%) & $\begin{array}{c}1,15 \\
(3,21 \%)\end{array}$ & $\begin{array}{c}4,37 \\
(13,43 \%)\end{array}$ & $\begin{array}{c}14,55 \\
(46,63 \%)\end{array}$ & $\begin{array}{l}6,69 \\
(20,18 \%)\end{array}$ \\
\hline 3 & Rice straw (kg, \%) & $\begin{array}{c}9,79 \\
(27,41 \%)\end{array}$ & $\begin{array}{c}5,74 \\
(17,64 \%)\end{array}$ & $\begin{array}{c}1,47 \\
(4,71 \%)\end{array}$ & $\begin{array}{l}5,67 \\
(17,10 \%)\end{array}$ \\
\hline 4 & Broadleaf (kg, \%) & - & $\begin{array}{c}0,52 \\
(1,59 \%)\end{array}$ & $\begin{array}{c}0,54 \\
(1,73 \%)\end{array}$ & $\begin{array}{l}0,35 \\
(1,06 \%)\end{array}$ \\
\hline 5 & $\begin{array}{l}\text { Gamal (Gliricidia) (kg, } \\
\%)\end{array}$ & - & - & $\begin{array}{c}3,17 \\
(10,16 \%) \\
\end{array}$ & $\begin{array}{l}1,05 \\
(3,17 \%) \\
\end{array}$ \\
\hline & Total & 35,72 & 32,53 & 31,20 & 33,15 \\
\hline
\end{tabular}

The use of gamal leaves in rations is very small (3.17\%), even in the lowlands and plains there is no finding of gamal leaves in the parent cattle ration.

Gamal has Rumen Degradable Protein (RDP) properties that can increase microbial protein in the rumen. Providing suitable N compounds in the rumen, will improve the status of breastfeeding cow protein and other productive ruminants, because RDP of peptides and AA stimulates microbial protein synthesis both in the amount and efficiency of proteins formed per unit of energy fermentation [12]. When viewed from the amount of feed given to main cows with an average of $33.15 \mathrm{~kg}$ in fresh weight assuming the weight of cattle is $300 \mathrm{~kg}$, then the amount of feed is sufficient for livestock based on the provisions of $10 \%$ of body weight.

\subsection{Fulfillment of Nutrition in a Diet}

Based on the composition of the ration given, it can be calculated the chemical composition and nutrient ration, which can represent nutrient fulfillment for Balinese cattle cows in Bali (Table 4).

Table 4. Fulfillment of Nutrients in a Diet

\begin{tabular}{llcccc}
\hline No & Variable & \multicolumn{4}{c}{ Average in ration } \\
\cline { 3 - 5 } & & Law land & Plains & Plateu & Everage \\
\hline 1 & Dry matter (kg) & 8,12 & 6,95 & 5,76 & 6,94 \\
2 & Crude fiber (\%) & 28,16 & 27,03 & 24,79 & 26,66 \\
3 & Protein (g) & 696,61 & 614,62 & 634,71 & 648,65 \\
4 & Energy (ME) (kkal.) & $16.275,84$ & $13.983,85$ & $11.200,84$ & $13.820,18$ \\
\hline
\end{tabular}

The average consumption of dry ingredients of ration $6.94 \mathrm{~kg}$ is slightly lower when referring to the standard [13] with a weight of $300 \mathrm{~kg}$ cattle required $7.2 \mathrm{~kg}$ of DM, but the weight of the cattle cows in the Simantri group is still lower. When referring to research [14] and [15], each of them states $5.40 \mathrm{~kg} /$ day and $5.7 \mathrm{~kg} /$ day, then the consumption of dry matter for parent Bali cattle is sufficient. When compared to research [4] during the rainy season the average dry material consumption of $6.47 \mathrm{~kg} /$ day was higher, meaning that in the dry season the water content of feed ingredients in the ration was lower.

Judging from protein fulfillment obtained an average of $648.65 \mathrm{~g} / \mathrm{day}$, it is still sufficient when compared to the standard [13], research [14] and opinions [15] respectively 
$614 \mathrm{~g}, 679.57 \mathrm{~g}$, and $432 \mathrm{~g} \mathrm{CP} /$ day. While from the study [4] at the end of the rainy season (February-March) protein consumption was $671.6 \mathrm{~g} /$ day higher. That means that entering the dry season (June-July) the amount of protein ration and protein consumption for Balinese cattle cows in Bali decreases due to several factors: 1) the diversity of feed ingredients in the ration decreases, 2) the quality of feed ingredients decreases due to increased crude fiber content.

From the aspect of fulfilling energy (ME) entering the dry season with an average of $13,820.18 \mathrm{kcal} \mathrm{ME} /$ day higher than at the end of the rainy season which is $12,650.7 \mathrm{kcal} \mathrm{ME}$ [4]. However, it is still higher when referring to standards [13], opinions [15], and research [14] respectively 12,400 kcal / day, 9,822.22 kcal / day, and 9,936.83 kcal / day. This shows that the high energy obtained by the bali cattle cows during the dry season is due to the use of a lot of grass and elephant grass, but it is not balanced with the provision of less legume leaves, the balance of energy / protein in the ration is not good.

\section{Conclusion}

From the description of the results and discussion, it can be concluded:

a. Maintenance of parent Bali cattle in Bali is still populist, still low land ownership for forage planting, still relying on finding another place

b. The minimum diversity of feed ingredients in the ration during the dry season, the greater use of field grass and the low supply of forage legumes. While the amount of feed given $33.15 \mathrm{~kg}$ (wet weight) and $6.94 \mathrm{~kg}$ (dry matter / DM) is sufficient for weight.

c. The amount of protein consumed in the ration is $648.65 \mathrm{gr} / \mathrm{oak} /$ day decreasing compared to the rainy season, but it is still sufficient for livestock. While the energy in the rations consumed with an average of 13,820.18 kcal ME / day is quite high above the basic necessities of life, even higher than the energy ration consumed in the rainy season.

\section{Acknowledgment}

To support data collection in Simantri group in scientific writing, we would like to thank the Bali Provincial Agriculture Office. Thanks also to group members as respondents who have worked together during the interview and observation process. Thanks also to the Rector of Warmadewa University who helped in funding this research.

\section{References}

[1] Darmadja S.G.:Setengah Abad Peternakan Sapi Tradisional dalam Ekosistim Pertanian di Bali. Disertasi, Universitas Padjadjaran, Bandung (1980)

[2] Nitis, I.M., K. Lana., \& A.W.Puger.: Pengalaman Pengembangan Tanaman Makanan Ternak Berwawasan lingkungan di Bali. Proceding Seminar Nasional. Sistim Integrasi Tanaman Ternak (1987)

[3] Suharto, M.: Dukungan Teknologi Pakan Dalam Usaha Sapi Potong Berbasis Sumber Daya Lokal. Makaah. Lokakarya Nasional Sapi Potong, Surakarta (2004)

[4] Sudita, I D.N., \& I. B. G. P. I.G.Mahardika., I W.Suarna.: Analysis of Feed for Digestibility Bali Cow in Group 'Simantri' Program in Bali on Defferent Topographic, Internasional Journal on Advanced Science Engeneering Information Technologi. Vol. 5(6) (2015)S 
[5] Diwyanto, K., \& I. G. A. . Mahendri.: Peran Sapi Bali dalam Mewujudkan Swasembada Daging Nasional yang Berkelanjutan. Naskah Lengkap Seminar Nasional Sapi Bali. Pusat Kajian Saoi Bali, Universitas Udayana (2013)

[6] Legates, J. E. \& E. J. Warwick.: Breeding and Improvement of Farm Animal. 8th ed. Mc GrowHill Book Co, New York (1990)

[7] Hardjosubroto, W.: Aplikasi Pemuliaan Ternak di Lapangan. Grasindo, Jakarta (1994)

[8] Astuti, M.: Pemuliaan Ternak, Pengembangan dan Usaha Perbaikan Genetik Ternak Lokal. Pidato Pengukuhan Guru Besar Ilmu Pemuliaan Ternak pada Fakultas Peternakan UGM, Yogyakarta (1999)

[9] Williams, C.M., J.S.Eun., J.W.MacAdam., A.J.Young., V.Fellner \& B.R.Min.: Effects of forage legumes containing condensed tannins on methane and ammonia production in continuous cultures of mixed ruminal microorganisms. Journal of Animal Feed Science and Technology, Elsevier. Vol. 167, pp. 364-372 (2011)

[10] Minson, D.J.: Forage in Ruminant Nutrition. Academic Press Inc, Sandiago (1990)

[11] Brask, M., P.Lund., A.L.F.Hellwing., M.Poulsen., \& M.R, Weisbjerg.: Enteric methane production, digestibility amd rumrn fermentation in dairy cows fed different forages with and without rapessed fat supplementation. Journal of Animal Feed Science and Technology, Elsevier. Vol. $172(2012)$

[12] Broderick, G.A.: Manipulation of the Dietary N-Fractions to Improve Ruminal Microbial Synthesis and Yield. Revious Revious Ruminant Nutrition Symposia, 24th Symposium (2011)

[13] Kearl, M.: Nutrient Requirements of Ruminants in Developing Countries. International Feedstuffs Institute. Agricultural Experiment Station Utah State University Logan, Utah USA (1982)

[14] Mariani, N.P.: Penentuan Kebutuhan Protein dan Energi Sapi Bali Sedang Tumbuh Berdasarkan Percobaan Pakan dan Komposisi Tubuh. Disertasi, Program Pascasarjana Universitas Udayana (2013)

[15] Leng, R.A.: Quantitatif Ruminant Nutrition-A Green Science. Australian Journal of Agricultural Research. Vol. 44(3). pp. 63-80 (1993) 